Suwarni La Usa

\title{
PENGARUH PENDEKATAN BRAIN BASED LEARNING DALAM PEMBELAJARAN MATEMATIKA TERHADAP HASIL BELAJAR SISWA KELAS VII PADA SMP NEGERI 2 BAUBAU
}

\author{
Suwarni La Usa \\ Dosen Pendidikan Matematika FKIP Unidayan \\ an_nyie03@yahoo.co.id
}

\begin{abstract}
Abstrak
Tujuan penelitian ini adalah untuk mengetahui pengaruh pendekatan berbasis otak (Brain Based Learning) terhadap hasil belajar matematika siswa kelas VII pada SMP Negeri 2 Baubau tahun ajaran 2015/2016. Penelitian ini adalah penelitian eksperimen. Metode penelitian yang digunakan adalah metode tes. Penentuan sampel menggunakan tekhnik purposive sampling dimana diperoleh siswa kelas $\mathrm{VII}_{4}$ sebagai kelompok eksperimen dan siswa kelas $\mathrm{VII}_{5}$ sebagai kelompok kontrol. Hasil penelitian menunjukan bahwa ada pengaruh yang signifikan pendekatan berbasis otak (Brain Based Learning) terhadap hasil belajar matematika pada siswa kelas VII SMP Negeri 2 Baubau tahun ajaran 2015/2016 sebesar 13,38\%. Berdasarkan hasil penelitian disimpulkan bahwa ada pengaruh pendekatan berbasis otak (Brain Based Learning) terhadap hasil belajar matematika pada siswa kelas VII SMP Negeri 2 Baubau.
\end{abstract}

Kata kunci: Brain Based Learning, Hasil Belajar Siswa

\begin{abstract}
The research aimed to know the influence of brain based learning approach toward mathematics learning outcomes of the students class VII SMP 2 in Baubau of 2015/2016 academic year. The research was a experiment research. Research method which be used are test method. Determined of the sample using purposive sampling technique which the students of $\mathrm{VII}_{4}$ class as experimental group and the students of $\mathrm{VII}_{5}$ class a . Pengambilan sampel dilakukan dengan tekhnik purposive sampling dimana diperoleh kelas $\mathrm{VII}_{4}$ as control group. The result of research revealed that there is significant influence of brain based learning toward mathematics learning outcomes of the students class VII SMP 2 in Baubau 2015/2016 academic year was 13,38\%. Based on the result of research can be concluded that there is significant influence of brain based learning toward mathematics learning outcomes of the students class VII SMP 2 in Baubau.
\end{abstract}

Keywords: brain based learning, mathematics learning outcomes

\section{PENDAHULUAN}

Pendidikan merupakan upaya sadar yang dilaksanakan secara teratur dan berencana untuk menyiapkan peserta didik melalui berbagai kegiatan baik berupa bimbingan, pengajaran maupun latihan agar kegiatan peserta didik dapat berperan dengan sebaik-baiknya dalam kehidupan berbangsa dan bernegara. Adapun tujuan pendidikan adalah adanya perubahan tingkah laku yang diinginkan terjadi setelah siswa belajar.

Pembelajaran matematika di sekolah saat ini yang masih berorientasi pada penggunaan otak kiri saja, ditambah alokasi waktu yang lebih banyak dibandingkan mata pelajaran lain membuat peserta didik mudah lelah dan jenuh.
Berdasarkan hasil wawancara dengan guru, dalam proses pembelajaran matematika siswa kurang memahami langkah-langkah pengerjaan. Terkadang siswa yang telah menguasai materi lupa ketika harus mengulang materi tersebut pada pertemuan berikutnya. Sehingga hasil belajar siswa menjadi rendah.

Hal itu terjadi karena dalam memberikan materi pelajaran, guru masih menggunakan model pembelajaran yang menekankan penggunaan otak kiri. Guru memberikan materi kepada siswa secara langsung dengan menggunakan metode ceramah. Guru kurang melibatkan siswa dalam proses pembelajaran. Pemberian materi dilakukan secara langsung sehingga kurang adanya kegiatan yang melibatkan keaktifan siswa dalam pembelajaran. Keaktifan yang dimaksud adalah keaktifan untuk 
Suwarni La Usa

bertanya jika belum paham pada materi dan keaktifan siswa untuk mengemukakan pendapatnya. Selain itu proses pembelajaran di kelas juga kurang melibatkan kekreatifan siswa. Padahal dengan melibatkan kekreatifan siswa dalam proses pembelajaran dapat menciptaka situasi yang baru, yang tidak monoton dan menarik sehingga siswa dapat terlibat secara aktif dalam proses pembelajaran. Jika guru melibatkan keaktifan dan kekreatifan siswa, maka proses pembelajaran siswa menjadi semakin bermakna dan menajamkan daya ingat siswa. Berdasarkan latar belakang masalah tersebut, maka salah satu pendekatan yang dapat digunakan pendekatan berbasis otak kiri (Brain Based Learning).

Menurut Jensen (2008, p.12), pembelajaran berbasis otak merupakan sebuah cara berpikir tentang proses pembelajaran. Pendekatan ini adalah pembelajaran yang diselaraskan dengan cara otak yang didesain secara alamiah untuk belajar. Jadi pembelajaran berbasis otak merupakan pendekatan pembelajaran yang menyesuaikan dengan kinerja otak dengan cara menggunakan kinerja otak kiri dan kanan.

Pedak dan Muslichan menjelaskan bahwa menurut para neurolog, kunci dari seseorang yang cerdas dan kreatif adalah mengupayakan agar belahan otak kiri dan kanan dapat berfungsi secara maksimal dan seimbang. Ketika belahan otak tersebut seimbang, maka kekuatan dan fungsi-fungsi otak manusia maksimal. Bahkan bekerjanyapun maksimal karena terjadi keseimbangan. Dampak positif yang bisa dirasakan dalam konteks ini ialah kecerdasan seseorang seorang anak akan semakin meningkat. Fungsi otak tersebut tidak hanya bekerja masingmasing tetapi saling mempengaruhi satu sama lain.

Hernowo (2008, p.68) juga mengungkapkan bahwa otak kreatif adalah otak kiri dan otak kanan yang bekerja sinergis. Dalam pembelajaran, hendaknya penggunaan otak kiri dan otak kanan diseimbangkan agar pembelajaran menjadi lebih bermakna.

Menurut Mudyaharjo pendidikan yang berbasis pada otak adalah sistem yang mengakomodasikan pengalaman-pengalaman atau kegiatan belajar yang diminati oleh setiap siswa. Sedangkan metodenya adalah lebih berupa penyediaan lingkungan dan fasilitas yang memungkinkan berlangsungnya proses belajar secara bebas pada setiap anak mengembangkan bakat dari minatnya masing-masing.

Ada 3 langkah yang berkaitan dengan cara mengimplementasikan pembelajaran berbasis otak, yaitu: 1) menciptakan suasana atau lingkungan yang mampu merangsang kemampuan berpikir siswa. Strategi ini bisa dilakukan terutama saat guru memberikan soalsoal untuk mengevaluasi materi pelajaran. Soalsoal yang diberikan harus dikemas seaktraktif mungkin sehingga kemampuan berpikir siswa bisa optimal seperti teka-teki, simulasi, permainan, dan sebagainya; 2) menghadirkan siswa dalam lingkungan pembelajaran yang menyenangkan. Guru tidak hanya memanfaatkan ruang-ruang kelas tetapi juga tempat-tempat lainnya. Guru harus menghindarkan suasana pembelajaran yang membuat siswa merasa bosan, tidak nyaman atau tidak suka terlibat di dalamnya; dan 3) membuat suasana pembelajaran yang aktif dan bermakna bagi siswa. Hal ini dapat dilakukan apabila siswa secara fisik maupun psikis dapat beraktivitas secara optimal. Strategi pembelajaran dikemas sedemikian rupa sehingga siswa terlibat secara aktif dan interaktif melalui pembelajaran yang bersifat demonstrasi.

Berdasarkan latar belakang tersebut, rumusan masalah dalam penelitian ini adalah apakah ada pengaruh penerapan pendekatan berbasis otak (Brain Based Learning) dalam pembelajaran matematika terhadap hasil belajar siswa pada kelas VII SMP Negeri 2 Baubau? Berdasarkan rumusan masalah tersebut, penelitian ini bertujuan untuk mengetahui pengaruh penerapan pendekatan berbasis otak (Brain Based Learning) dalam pembelajaran matematika terhadap hasil belajar siswa pada kelas VII SMP Negeri 2 Baubau.

\section{METODE PENELITIAN}

\section{Jenis Penelitian}

Penelitian ini termasuk penelitian eksperimen dengan menggunakan bentuk preeksperimental design.

\section{Waktu dan Tempat Penelitian}

Penelitian ini dilaksanakan pada semester genap pada bulan Maret 2016 dan berakhir pada bulan Juni 2016 di SMP Negeri 2 Baubau.

\section{Populasi dan Sampel}

Populasi dalam penelitian ini adalah seluruh siswa kelas VII SMP Negeri 2 Baubau tahun ajaran 2015/2016 yang terdiri dari 16 kelas. Pengambilan sampel dilakukan dengan teknik purposive sampling dengan mengambil kelas $\mathrm{VII}_{4}$ yang berjumlah 28 siswa sebagai kelompok eksperimen yang memperoleh pembelajaran 
Suwarni La Usa

dengan pendekatan brain based learning dan kelas $\mathrm{VII}_{5}$ yang berjumlah 28 siswa sebagai kelompok kontrol yang memperoleh pembelajaran konvensional.

\section{Intsrumen dan Teknik Pengumpulan Data}

Instrumen yang digunakan dalam penelitian ini berupa tes dalam bentuk essay sebanyak 8 butir soal yang diberikan setelah memperoleh pembelajaran baik pada kelompok eksperimen maupun kelompok kontrol. Tes ini digunakan untuk memperoleh data nilai hasil belajar matematika siswa

\section{Teknik Analisis Data}

Analisis data dilakukan setelah pengumpulan data. Teknik analisis menggunakan teknik analisis data kuantitatif. Untuk menguji hipotesis dengan menggunakan uji statistik $t$-test, dengan rumus:

$$
t_{-} \text {test }=\frac{\bar{X}_{1}-\bar{X}_{2}}{\sqrt{\left[\frac{S D_{1}{ }^{2}}{N_{1}-1}\right]+\left[\frac{S D_{2}{ }^{2}}{N_{2}-1}\right]}}
$$

\section{HASIL PENELITIAN DAN PEMBAHASAN}

Sebelum dianalisis, terlebih dahulu akan dilakukan uji normalitas dan uji homogenitas. Uji normalitas untuk mengetahui data berdistribusi normal atau tidak. Berdasarkan hasil analisis diperoleh nilai signifikansi untuk setiap data lebih besar dari 0,05 yang berarti data tersebut berdistribusi normal. Uji homogenitas untuk mengetahui apakah sampel benar-benar homogen. Berdasarkan hasil analisis diperoleh nilai signifikansi lebih besar dari 0,05 maka sampel tersebut homogen.

\section{Pengujian Hipotesis}

Berdasarkan hasil perhitungan dengan uji statistik $t$-test diperoleh Hasil perhitungan t-test sebesar 2,38 tersebut disebut $t_{\text {hitung. Untuk }}$ menentukan taraf signifikasi perbedaannya harus digunakan $t_{\text {tabel }}$ yang terdapat pada tabel nilainilai t. Sebelum melihat tabel nilai-nilai t, terlebih dahulu harus ditentukan derajat kebebasan $(\mathrm{db})$ pada keseluruhan sampel yang diteliti dengna rumus $\mathrm{db}=\mathrm{N}-2$. Karena jumlah sampel yang diteliti adalah 56 peserta didik, maka $\mathrm{db}=56-2$ $=54$ dengan taraf signifikasi $5 \%$ ditemukan $t_{\text {tabel }}$ $=1,68$ dan. Dengan demikian $t_{\text {hitung }}>t_{\text {tabel }}$ maka $\mathrm{H}_{1}$ diterima.

\section{Pembahasan}

Berdasarkan hasil analisis data tahap awal diketahui bahwa data dari masing-masing kelas berdistribusi normal dan kedua kelas yang merupakan sampel penelitian mempunyai varians yang sama (homogen). Hal ini dapat diambil kesimpulan bahwa sampel mempunyai kondisi awal yang sama..

Pada pelaksanaan penelitian, jumlah waktu pembelajaran yang diberikan pada kelompok eksperimen dan kelompok kontrol adalah sama yaitu 5 jam pelajaran. Dengan rincian 4 jam digunakan untuk pembelajaran dan 1 jam pelajaran digunakan untuk test. Selain jumlah waktu pembelajaran yang sama, pokok materi yang disampaikan pada kelompok eksperimen dan kelompok kontrol juga sama yaitu segi empat. Jadi perlakuan yang berbeda hanya pada pendekatan pembelajaran yang digunakan. Pada kelompok eksperimen pembelajaran dengan penerapan pendekatan berbasis otak (brain based learning) sedangkan kelompok kontrol dengan pembelajaran konvensional.

Variabel bebas dalam penelitian ini adalah proses penerapan pendekatan berbasis otak (brain based learning) pada pembelajaran matematika, sedangkan variabel terikatnya adalah hasil belajar siswa (post test).Untuk mengetahui apakah pembelajaran dengan pendekatan berbasis otak (brain based learning) berpengaruh terhadap hasil belajar siswa digunakan uji perbedaan dua rata-rata. Data yang digunakan untuk menganalis uji perbedaan dua rata-rata adalah data nilai post test pokok materi segi banyak yang diberikan pada akhir pembelajaran. Rumus yang digunakan adalah uji- t. Hal ini disebabkan karena kelompok eksperimen dan kelompok kontrol mempunyai varians yang sama. Berdasarkan hasil perhitungan diperoleh t-test sebesar 2,38 tersebut disebut $t_{\text {hitung }}$ dan jumlah sampel yang diteliti adalah 56 peserta didik, maka db $=56-2$ $=54$ dengan taraf signifikasi $5 \%$ ditemukan $t_{\text {tabel }}$ $=1,68$ maka dapat disimpulkan hasil belajar kelompok eksperimen lebih baik dari pada kelompok kontrol. Oleh karena pembelajaran dengan pendekatan berbasis otak (brain based learning) dapat meningkatkan hasil belajar pada kelas eksperimen sehingga hipotesis yang menyatakan bahwa ada pengaruh antara pendekatan berbasis otak (brain based learning) terhadap hasil belajar matematika di SMP Negeri 2 Baubau diterima.

Hasil penelitian tersebut menunjukkan bahwa pembelajaran matematika dengan 
Suwarni La Usa

Pendekatan Berbasis Otak (Brain-BasedLearning) lebih baik daripada pembelajaran matematika konvensional. Hal ini sesuai dengan teori Pendekatan Berbasis Otak (Brain-BasedLearning) dimana siswa dapat mendorong kinerja otak kanan dan otak kirinya dalam proses pembelajaran, dengan harapan dalam proses pembelajaran siswa tidak merasa jenuh dan materi pembelajaran yang diterima siswa dapat bertahan lama. Pendekatan pembelajaran berbasis otak merupakan sebuah cara berpikir mengenai proses pembelajaran yang diselaraskan dengan cara otak yang didesain secara alamiah untuk belajar sehingga hasil belajar matematika siswa dapat meningkat.

\section{KESIMPULAN DAN SARAN}

\section{Kesimpulan}

Berdasarkan hasil penelitian disimpulkan bahwa terdapat pengaruh penerapan pendekatan berbasis otak (brain based learning) terhadap hasil belajar matematika pada siswa kelas VII SMP Negeri 2 Baubau tahun ajaran 2015/2016.

\section{Saran}

Sebagai seorang guru harus berfikir kritis dan mampu berkreatifitas. Seorang guru harus mampu menciptakan suasana belajar yang menyenangkan dan membuat siswa antusias terhadap materi yang sedang berlangsung sehingga mereka mampu mengikuti dan memahami materi yang disampaikan. Guru perlu membantu memaksimalkan kinerja otak siswa dan menggunakan pendekatan serta metode pembelajaran yang tepat. Salah satu pendekatan yang harus dikuasai yaitu pendekatan brain based learning.

\section{DAFTAR PUSTAKA}

[1] Dalyono. (2007). Psikologi Pendidikan. Jakarta: Rineka Cipta.

[2] Simbolon, F.S. (2010). Pembelajaran Berbasis Otak. Diakses bulan Maret 2016 dari http:www. Mgt-sdm.blogspot.

[3] Hudojo, H. (1990). Strategi Mengajar Belajar Matematika. Malang: Penerbit IKIP Malang.
[4] Jensen, E. (2008). Brain Based Learning: Pembelajaran Berbasis Kemampuan Otak. Yogyakarta: Pustaka Pelajar.

[5] Jihad, A., \& Haris, A. (2009). Evaluasi Pembelajaran. Yogyakarta: Multi Pressindo.

[6] Kadir, A. (2010). Misteri Otak Kiri Manusia. Yogyakarta: Diva Press.

[7] Sardiman, A.M. (2007). Interaksi dan Motivasi Belajar Mengajar. Jakarta: Raja Grafindo Persada.

[8] Suherman, E., dkk. (2006). Strategi Pembelajaran Matematika Komtemporer. Bandung: Universitas Pendidikan Indonesia.

[9] Soedjadi, R. (1999). Kiat Pendidikan Matematika di Indonesia: Konstatasi Keadaan Masa Kini Menuju Harapan Masa Depan. t.t.: Direktorat Jenderal Pendidikan Tinggi Departemen Pendidikan Nasional.

[10] Syah, M. (2003). Psikologi Belajar. Jakarta: Raja Grafindo Persada.

[11] Winkel, $\quad$ W.S. (1999). Psikologi Pengajaran. Jakarta: Grasindo.

[12] Widinarto. (2009). Pembelajaran Bebasis Otak..Diakses bulan Maret dalam http//www.Wordpress.com. 